\title{
MAXIMILIAN VOLOSHIN'S JAPANESE PRINT COLLECTION IN THE CONTEXT OF EUROPEAN ORIENTALISM
}

\author{
DARYA KOLTSOVA \\ dkoltsova@yandex.ru \\ Kharkiv State Academy of Design and Art, \\ Ukraine
}

\begin{abstract}
The paper is concerned with Maksimilian Voloshin's Japanese woodblock print collection. It starts with a short historical sketch of Orientalism in Europe and Russia, illustrating various highlights and the evolution of the image of the East in the minds of Europeans, and designed so that the emergence of Voloshin's interest in Japanese art and his activity of collecting Ukiyo-e prints can be considered in the context of European Orientalism.

Key words: Japanese woodblock prints, Ukiyo-e, Orientalism, Japanism, Voloshin, collecting activity.

Several studies have been conducted on the problem of the influence of Japanese art on the work of Maksimilian Voloshin, Russian poet and painter of the Silver Age, particularly E. Dyakonova (2004, 2006), N. Gryakova (2004), N. Konshina (2006), D. Shabashov (2007).

However, Voloshin's passion for oriental culture also affected his art critics as well as his collecting activity. The Japanese Ukiyo-e prints he acquired comprise the House-museum of Voloshin's (Koktebel, Crimea) permanent exposition. Despite this fact, the collection has never become a focus of study. Several mentions and a catalogue of the entire collection compiled by Aynura Yusupova (2004) make up almost all that today's science has on the subject. Although Yusupova has made a preliminary attribution of the prints, the museum documentation is still lacking any data on the prints, including authorship and titles, thereby requiring an in-depth investigation. At the same time, Voloshin's Japanese collection requires an analysis of the broader scientific discourse in the context of European Orientalism of the late $19^{\text {th }}$ - early $20^{\text {th }}$ century.

The problem of Orientalism, as a phenomenon in European culture, has been much discussed in recent literature. Among scholars who have worked on the subject and made enormous contributions are E. Said (1978), R. Kabbani (1994), J. Meagher (2000), M. Stevens (1984), N. Konrad (1972). Therefore, without going into specific details we will mention only highlights of its development in Europe.

A term "Orientalism" has existed in Europe from the beginning of the $18^{\text {th }}$ century, embracing the entire set of studies of material and spiritual culture of the East (Asian studies). Simultaneously, the term refers to the imitation, depiction
\end{abstract}


or assimilation of oriental (Middle Eastern and East Asian) themes, motifs and stylistics in Western art.

In its early phase, Orientalism, as an area of scientific knowledge, was tied to the colonial expansion by Western countries that became the topic of Edward Said's study (1978). The author associated Oriental studies with a problem of colonialism and imperialism, in fact, defining domination in the East as a main purpose of Orientalism as a system of Western knowledge. During its initial period, a massive body of fiction and scientific literature based on numerous investigations of oriental languages, texts and travel books was created. In parallel, Jesuits, perceiving it as an object of missionary activity and spread of the Christian faith, actively encouraged interest in the Orient.

The following wave of fascination with the Orient started in the $18^{\text {th }}$ century, predominantly relating to Arab and Chinese cultures. This time, the developed escapist idealistic Eastern conceptions, turned it into a subject of contemplation or even utopian images for many prominent European scientists and philosophers (G.W. Leibniz, Voltaire, Ch. de Montesquieu, D. Diderot and others). Many collections of Oriental art and books were formed during the $18^{\text {th }}$ century. While the utopian tone of the ideas about the East became a typical feature of these times, genuine realities and the highest values of Oriental culture, generally have not fallen into the Europeans field of view. In many respects, the interest in the East was per se no more than a vogue for an exotic, romanticized aesthetic ideal of "heaven on earth" and had no relation to reality. Thus Voloshin deplored in his article about painter Martiros Saryan that "rather than grasp the Eastern creation methods, they (artist and writers) notice only a scattering of picturesque subjects and themes" (1913, p. 303). Besides, it is significant that the East has not been localized, containing China (Japan was usually included in its average idea), India, and the Arab countries, thereby emphasizing the construction of an imagined geography, as a part of the Eastern Utopian image, firstly in the minds of Enlighteners and then the Romantics.

During the first half of the $19^{\text {th }}$ century, Orientalism began to acquire a character of quite delineated trend in European art (especially French ) and science that was in large part stimulated by several historical events in the East. For instance, Napoleon's Egyptian campaign (1798 - 1799) with the participation of painters, making the first full-scale sketches and scientists - the future Institute of Egypt bringing representatives of all branches of science together. It was followed by the Greek war for Independence (1821 - 1829), the conquest of Algiers by the French (1830), and the opening of the Suez Canal (1869). As a consequence, the scientific field of Oriental studies as well as Oriental currents in European cultures changed fundamentally. Thus, in the mid $-19^{\text {th }}$ century Orientalism acquired academic discipline significance that was directly reflected in a qualitatively new stage of Oriental studies and a radical redefinition of the role and importance of the East for the West. On the other hand, in the second half of the $19^{\text {th }}$ century an opportunity for a direct dialogue between Western and Eastern artists emerged and fueled their creative imaginations which led to an extraordinary outburst of creative energy, marking artistic life of European countries in the final third of the $19^{\text {th }}$ century - the time of the most active non-European cultures' lessons assimilation. 
After 1860 a craze for the art of the Land of the Rising Sun replaced the fad for "spicy Arab and China exotic". Japan became localized and individualized in the Europeans' perception, mainly through the art of Japanese Ukiyo-e prints (pictures of the floating world). The first Japanese woodblock prints reached Europe in the late $18^{\text {th }}$ century (Nikolaeva, 1996) and in the 1830s, European audiences got the opportunity to meet the art of Japan in museums, exhibitions, and special illustrated editions. Next, the publication of a number of books in the late 1850's and early 1860s generally illustrated by Japanese prints became an important step in being acquainted with Japan (Alcock, R. (1863). The Capital of the Tycoon; Fraissinet, E. (1857). Le Japon contemporain; Osborn, Sh. (1861). Japanese Fragments; Lindau, R. (1864). Voyage autour du Japon; Montblanc, Ch. (1865). Le Japon,).

Following the Meiji Restoration, Japan ended a long period of seclusion and thus an opportunity of direct contacts between Western and Eastern cultures emerged. "Japonism", as one of the orientalizing styles, gained popularity among the scientific and artistic communities of Europe.

Therefore, cafes in "Japanese taste" appeared in London and Paris, novels from Japanese life were published, plays and even operas with Japanese subjects were staged, like for instance: La princesse jaune (1872), Kosiki (1876), Marjoram (1877), and Mikado (1885). Hence, for the first time the general French and British public paid attention to the art of Japan in the late 1850s. And in only about 20 years, European painters became ready to accept the artistic traditions of Japan, turning them into structural elements of their own creative method, in contrast to the thematic manifestation of the previous century Orientalism. Collecting Japanese Ukiyo-e prints, which were sold at The Great Exhibitions, as well as in numerous special stores such as La Porte Chinoise, La maison Sichel, and L'Art nouveau Bing, had turned into a typical craze of the European art world. As a result, in the late 1860s the problem of the impact of Japanese art (mostly Ukiyo-e prints) on European painters, graphics and industrial designers fell into the field of critical discourse (Astruc, Z. (1868). Le Japon chez nous; Chesnot, L. (1869). L'art japonais; Evett, E. (1982). The critical reception of Japanese art in Europe in late nineteenth century).

Significantly later, merely by the end of 1890s the fad for Japanese art became noticeable in Russia, having two ways of penetration: directly at the exhibitions of Japanese art held in Moscow and Saint Petersburg, and through the European medium, whose literal and artistic tradition influenced Russian $19^{\text {th }}$ and $20^{\text {th }}$ century society. In this light, emphasizing the problem of European mediation, N. Konshina mentioned in her dissertation the fact that the majority of that period's Japanese poetry translations were completed into Russian from European languages (Konshina, 2006). Thus, Russian graphics and painters typically met and started adopting Japanese elements or style through paintings of Claude Monet, Edgar Degas, Aubrey Beardsley, Henri de Toulouse-Lautrec and others. Moreover, Japonism in Russia proceeded in a similar way, being reduced to the thematic manifestation foremost and only henceforth its stylistic impact (conventional decoration, lack of perspective, off-centered arrangements, vibrant colors on plain surfaces etc) was perceived.

Japanese collections of N. Kitaev $(1896,1897,1905)$, S. Sherbatov $(1901$ - 1902), Hashegawa (1905), N. Kolobashnikov (1906) exhibited in Russia became the first 
direct acquaintance of the mass Russian viewer with the art of "The Land of the Rising Sun", which afterwards sparked numerous articles in the press and specialized publications. In turn, the first Russian book on the art of Japanese woodblock color printing written by the painter and Ukiyo-e prints collector Igor Grabar was published in 1903, followed by ensuing professional publications. As a result, many Russian painters, art critics, writers and scholars paid significant attention to the culture of Japan and started collecting Ukiyo-e prints. Of particular note are S. Sherbatov, A. Benua, D. Mitrohin, V. Gorshakov, A. Ostoumova-Lebedeva and others.

As well as Maksimilian Voloshin (1877 - 1934), Russian poet and painter of the Silver Age, who took an interest in Japanese art that significantly influenced his literary and artistic heritage. Besides, Voloshin assembled an Ukiyo-e prints collection exhibited today in the House museum of M. Voloshin in Koktebel (Crimea, Ukraine). The small collection of 24 prints predominantly consists of the late Edo period engravings representing the Utagawa school for the most part and early Meiji prints, not included in the exposition. The highlights of the collection are the first plate from the series Lives of the True and Faithful Vassals of Kuniyoshi Utagava (1797 - 1861) and tree prints from Ando Hiroshige's (1797 - 1858) most famous series Views of Famous Places at the Fifty-three Stations of the Road Tokaido, Views of Sixty Odd Provinces and One Hundred Views of Edo. A quite rare depiction of a whaling scene, probably a part of one of Katsushika Hokusai's (1760 - 1849) Manga book and Mother and child of Kitagawa Utamaro (1753 - 1806) - reprint of the late $19^{\text {th }}$ - early $20^{\text {th }}$ as Yusupova presumed (Japanese prints in the collection of Maksimilian Voloshin, 2004) - add a major sound to the Voloshin's assemblage. Apparently, the collection was gathered spontaneously, but yet, a special variety of genres should be noted. Thus, all the major genres of Ukiyo-e prints are presented in the collection: bijinga (pictures of beautiful women), yakusha-e (prints of kabuki actors), mushya-e (pictures of warriors and legendary battle scenes), fukei-ga (landscape prints), kachō-ga (pictures of flowers and birds) and genre scenes (fuzoku-ga) from the everyday Tokyo life of the Meiji era.

At the same time, Voloshin did not reduce Japonism to the collecting activity, being passionate about the Orient culture in general (by studying history of civilizations of the East, Buddhism, the Koran, Indian mythology etc) and the Japanese one in particular, which affected all Voloshin's activities, having found a deep reflection in his literary, artistic and critical heritage. Thus, the question of the cause of Voloshin's enthusiasm for the Japanese art, despite its typicality in the context of the epoch, seems to be quite logical withal the problem of the offset point after which a Russian poet, raised on the Wanderers (Itinerants) paintings, compared Europe with a "green and succulent cactus, grown on the immense rocky deserts of Asia", emphasizing that "all life-currents - religion and art - it (Europe) drank from its (Asian) excess" (Saryan, 1913).

Displacement of his preferences for the Orient occurred at the turn of the century. Thus, Voloshin called 1900 the year of his spiritual birth (Voloshin,1925). That year Voloshin was exiled to Tashkent, where he discovered the culture of the East at first-hand. There he climbed the Pamir, reached the border with China and Mongolia, and "walked with caravans through the desert" (Voloshin, 1925). 
In parallel, Voloshin discovered Beyond Good and Evil of F. Nietzsche and Three conversations of Russian philosopher V. Solovyov with the Pan-mongolism theory (threat from the Far East). Solovyov's ideas of the so-called "yellow danger" and an unavoidable future confrontation of Europe and Asia have had a huge impact on contemporaries for many years and received the highest recognition in connection with the Russian-Japanese War (1904 - 1905). It should be noted that simultaneously Russians perceived Japan, organically included in the idea of the East, as a mythologemes of "the Lost Paradise", thence its idealization and utopian representation.

On the contrary, the impact of the Pan-mongolism idea on Voloshin consisted prima facie in only approving the problem of cultural and historical relativity and thereby enabled, quoting the poet, "to look at the whole of European culture in retrospect - from the height of the Asian highlands and reassess cultural values" (Voloshin, 1925, p. 38). At the same time Voloshin monitored attentively the events in China. In his letters, he truly expressed sympathy for the Ihetsyuans, criticizing the colonial policy towards the "out-of-European nations" (Voloshin, 1991, pp. 113, 117 - 118). So, staying in Asia has given Voloshin another angle of vision experience, the echoes of which would be encountered in many of his later works. "Asia burned the poet being imprinted in the experience of his body and giving growth of the organic imagery of his ensuing creation", - summarized Voloshin Turkistan staying N. Gryakova (2004, p. 30).

Time spent in the Middle East directly exploring its culture has led to the desire to learn from the Eastern civilizations of India, China, and Japan. Thus, it is remarkable that Voloshin was motivated by the intention to grasp the essence of the Eastern culture, not its imagined idea. In this manner, he considered it necessary to comprehend the origin of European culture foremost in order to discard it and in order to be ready to "get into the spirit of the new entity" (Voloshin, A letter to Petrova: February 12, 1901).

In the early years of the $20^{\text {th }}$ century Voloshin still perceived the East through the romantic prism, though he has already preferred its truthful image as opposed to the idealized one. In a while, China, Japan and India were localized and concretized in his mind: China was associated with its political system, India with philosophy, Japan with art. Henceforward his passion for the art of Japan began (particularly Ukiyo-e prints), which he came across most likely in Paris, where Voloshin intended to become an art critic in 1901.

At the Impressionist and the Post-impressionist exhibitions (The Nabis, for instance) he discovered European Japonism. He also read The Journal of the Goncourt brothers - the pioneer prophets of Japanese art in Europe. In addition, the young critic attended lectures on the history of religions at the Sorbonne, on art history at the Ecole du Louvre, studied painting at the Academy of Colarossi, and copied Japanese prints in the National Library. That year he got involved in Buddhism, read The light of Asia of Sir E. Arnold and met Hambo Lama Agvan Dorzhiev. All of the above reinforced Voloshin's desire for the cultural and spiritual pilgrimage to the East (to Baikal and then to Japan). The culmination happened in April 1902, when Voloshin took the true "initiation" into the world of Japanese Ukiyo-e prints 
at the pre-auction exhibition of the Samuel Bing collection arranged in Hotel des Ventes, demonstrating 1800 prints of the highest rank.

Although the first documentary evidence of Voloshin having Japanese prints in his collection relates to 1904, considering all the events mentioned above, the beginning of their acquisition can be assumingly be attributed to the 1902. Later that year in Saint Petersburg life brought him to enthusiastic collectors of "pictures of the floating world" A. Benua, E. Lanceray, I. Grabar. New contacts became a source of valuable information, first-hand visual experience and useful advice on the purchase issue.

Generally, Ukiyo-e prints were sold in antique shops and salons trading overseas rarities. These were prevalent in Europe in contrast to Russia, where the only possibility of getting Japanese woodcuts, mentioned in studies, related to the appearance in Saint-Petersburg in 1902 of a Japanese Hashegawu, consisting of visiting artists selling Japanese prints "at a reasonable price" (Dyakonova, 2006). Nevertheless, in Paris Voloshin had many more opportunities to start collecting prints so the suggestion seems to be quite reasonable. Thus, meeting Ukiyo-e collectors and theoreticians, discovering the highest rank samples, improving his knowledge of the East and beginning to gather the collection have marked Voloshin's first years of the 20th century.

In 1904, the artist wrote the article The Skeleton of painting, resuming that period of thought. The article went to the comparative analysis of Japanese and European art, recorded that summer in his notebook. The idea of European art renovation through Japanese art's great and radical impact became the dominant topic.

The Russo-Japanese War (1904 - 1905) gave new resonance to Russian Japonism. Russian scholars and collectors of the art of Japan were confident in undoubted future victory of the Russian Empire, thus only lamenting the fate of the Japanese culture. "Poor Hiroshige! Russian colonels will own the world's best collections" - wrote I. Grabar in a letter to the art critic S. Yaremich (1905). During the wartime, Voloshin had been working as an art director of a Symbolist magazine Vesy, publishing a so-called "Japanese editions" illustrated with Japanese vignettes, watercolors on the cover. Polemics in the magazine were painted in colonial Orientalism, sometimes even racist tone, emphasizing the fact that Russia did not take the war seriously.

Instead, Solovyov's gloomy "yellow danger" predictions partially came true. As a result, Eurocentric positions were revised. In contrast, Voloshin's priorities for the axis East - West shifted a long time ago (in 1900). Besides, in Paris he was distanced from the national humiliation and crashing geographic imperialism idea. So he watched the war through the Western European prism, looking forward to the radical European renovation through the Eastern culture.

That year in a letter to his future wife, M. Sabashnikova, he mentioned for the first time buying an Ukiyo-e print - Thunderstorm and Downpour in Kameyama plate 47 of the famous Utagawa Hiroshige series Fifty-three Stations of the Tokaido Road. "Now I feel myself being in a human environment. I have a desk. The candle burns. There are Japanese on the wall" - he described his Parisian parlor in the following letter to Sabashnikova.(Voloshin, A letter to Sabashnikova: September 
19, 1905). The letter together with the photos of Voloshin in the interior made in 1904, allow us to assert that the major part of his Ukiyo-e collection has been gathered by that time.

Explanation that Voloshin did not mention the purchase of other prints until 1904 is obvious. Apart from a few engravings, his assembly consisted of woodcuts of the late Edo period (1603 - 1868) and early Meiji (1868 - 1912) which was unusual at the time given that most prints reaching the west were, as a rule, by contemporary Japanese artists of the 1860s and 1870s. At the same time, the prints from that period did not win deserved recognition and were maintained to be vulgar and very far from the refined masterpieces of classical Edo period or earlier. Thus, Voloshin did not consider Utagawa Kunisada, Utagawa Kuniyoshi or Shosai Ikkei prints worth mentioning, in contrast to the engraving of Ando Hiroshige, renowned in Europe due to the numerous exhibitions, articles, illustrations, and special studies.

By 1906 his collection had been assembled and took its place in the interiors of Voloshin's house in Koktebel (Crimea), which became a kind of a center of attraction for the representatives of Russian culture of the Silver Age. In Koktebel Voloshin was engaged in painting and writing, addressing the question of Oriental art in his critical articles and notes. He dreamed about "the Land of the Rising Sun" and missed Parisian Orientalism, preparing for an unrealized trip to Japan (he even resumed his study of Japanese language), rereading the Goncourt brothers and getting excited about Remy de Gourmont, Paul Claudel and other French writers, affected by the Eastern culture. Thereat Japanese art influenced his watercolors, which were sometimes even reproached for the resemblance to the Ukiyo$e$ prints. So for instance, Voloshin started interweaving poetry in his paintings, which was one of the characteristic features of Japanese art.

\section{CONCLUSIONS AND FUTURE STUDIES}

In summary, the following implications can be made:

1. Orientalism in Europe had two paths of development: as a scientific discipline (Oriental studies) and as a system of the influence of Oriental arts on those of the West. As well, it is possible to distinguish two types of Oriental impact: thematic and stylistic.

2. The craze for Orientalism among the European general audience was largely attributed to the historical events in the East, such as the Egyptian campaign, the opening of the Suez Canal, the end of Japanese seclusion etc. As a result, numerous collections of Arab, Chinese, Japanese books and artworks appeared in Europe. From the $17^{\text {th }}$ to the $19^{\text {th }}$ centuries the initially Utopian image of the East in the minds of Europeans has turned into a more real (although still quite romanticized) and localized one.

3. Maksimilian Voloshin's interest in the Orient emerged through European mediation: indirectly (via the paintings of European artists who had assimilated the Oriental style) and directly (due to the Japanese art widely exhibited and sold in Paris). In their turn, Russian Ukiyo-e print collectors 
and scholars assisted in improving Voloshin's knowledge of Japanese culture and religion.

4. Voloshin started collecting Ukiyo-e prints in early 1902. The collection was assembled in Paris, apparently simultaneously and amateurishly. However, the collection is characterized by the variety of genres, including $b i$ jinga, yakusha-e, mushya-e, fukei-ga, kachō-ga and fuzoku-ga. The collection composition was quite typical for the time, consisting of prints of the late $19^{\text {th }}$ century represented mostly by artists of the Utagawa dynasty, and separately prints of prominent masters as Kitagawa Utamaro, Ando Hiroshige, Katsushika Hokusai and engravings of the Meiji period.

5. Voloshin's intention to grasp the essence of Oriental culture together with the radical revision of the Eurocentric ideas were ahead of his time in Russia, being typical for European Orientalism of the late $19^{\text {th }}-$ early $20^{\text {th }}$ century.

6. Despite the fact that the collection had been considered until the present to be preserved in its original composition, the study came across a picture of Voloshin in his "Winter Study" in Koktebel house, which also showed six Ukiyo-e prints (bijinga triptych and three separate engravings) which are not registered in the museum's collection today. Moreover, museum documentation also lacks any reference on the issue, neither have museum researchers any information. Thus, an intensive exploration of the photo collection of the museum with an ensuing analysis would probably shed light on the problems of the original composition of the assembled collection and preferences of the collector.

\section{ACKNOWLEDGEMENTS}

I would like to express my deep gratitude to Professor Svetlana Rybalko, my research supervisor, for her professional guidance and useful critiques. I would also like to thank the staff of the House - museum of M. Voloshin and especially N. Miroshnichenko, Director of the museum, for enabling me to study its collection.

Finally, I wish to acknowledge the help provided by Dr. Tsarkova T.S., Head of the Manuscript Department of the Russian Literature Institute (Pushkin House) of the Russian Academy of Sciences.

\section{REFERENCES}

Dyakonova, E. M. (2006). Japonisme in Russia in the Late Nineteenth and Early Twentieth Centuries. Russo-Japanese Cultural Contacts through Visual Media: Pictures and Artcrafts as Image Makers. In: Y. Mikhailova, M.W. Steele (eds.), Japan and Russia. Three centuries of mutual images (pp. 156-186). Folkestone: Global Orient.

Grabar, I. [Грабарь, И.] (1903). Японская иветная гравюра на дереве [Japanese colour woodcut]. Moscow: Tovarishestvo R. Golike i A. Vilborg.

Gryakalova ,N. [Грякалова, Н.] (2004). Война на Востоке и кризис европейских ценностей: (евроазиатский маршрут Максимилиана Волошина) [War in the East and the crisis of European values (Euro-Asian routes of Maksimilian Voloshin)]. Русская Литература, 3, 29 - 39.

Kabbani, R. (1994). Imperial Fictions: Europe's Myths of Orient. London: Pandora Press. 
Konrad, N. [Конрад, Н.] (1972). Запад и Восток [West and East]. Moscow: Nauka.

Konshina, N. [Коньшина, Н.] (2006). Влияние японской гравюры на литературу и живопись России конца XIX - начала XX Вb. (Кандидатская диссертация) [Impact of Japanese culture on Russian literature and art of the early $19^{\text {th }}$ - early $20^{\text {th }}$ century. (Phd dissertation)]. Saratov State Technical University, Saratov.

Kupchenko, V.P. [Купченко, В.П. ] (еd.) (2002). Труды и дни Максимилиана Волошина. Летопись жизни и творчества. 1877 - 1916 [Works and days of Maksimilian Voloshin. The chronicles of life and art. 1877 - 1916]. V. SPb: Aletheia.

Kupchenko, V.P. [Купченко, В.П. ] (еd.) (2007). Труды и дни Максимилиана Волошина. Летопись жизни и творчества. 1917 - 1932 [Works and days of Maksimilian Voloshin. The chronicles of life and art. 1917 - 1932]. V. SPb: Aletheia.

Meagher, J. (2000). Orientalism in Nineteenth-Century Art. New York: The Metropolitan Museum of Art.

Nikolaeva, N. [Николаева, Н. С.] (1996). Япония - Европа. Диалог в искусстве [Japan - Europe. Dialogue in Art]. Moscow: Izobrazitelnoe iskustvo.

Said, E.W. (1978). Orientalism. New York: Pantheon Books.

Shabashov, D. [Шабашов, Д.] (2007). Образ Востока в творчестве Максимилиана Волочина. (Кандидатская диссертация) [The East Mode in Maksimilian

Stevens, M. A. (1984). The Orientalists: Delacroix to Matisse: European Painters in North Africa and the Near East. Exhibition catalogue. London: Royal Academy of Arts.

Voloshin Voloshin's creativity. (Phd dissertation)]. Moscow: Moscow State Pedagogical University.

Voloshin, М. [Волошин, М.] (1988). М.С.Сарьян. Лики творчества [M.S. Saryan. Faces of creativity]. Leningrad: Nauka.

Voloshin, М. [Волошин, М.] (1911). Автобиография. Максимилиан Волошин [Autobiography. Maksimilian Voloshin]. Coasts of Koktebel. Symferopol: Tavriya.

Voloshin, М. [Волошин, М.] (1988). Лики творчества [Faces of creativity]. Leningrad: Nauka.

Voloshin, М. [Волошин, М.] (1991). Из литературного наследия. Вып. I [From the literary heritage. № 1.]. СПб: Nauka.

Yusupova, А [.Юсупова, А.] (2004). Японская ксилография b собрании Максимилиана Волотина. Сокровища Дома Волошина [Japanese prints in the collection of Maksimilian Voloshin. Treasures of Voloshin House]. Simferopol: SONAT. 